UDC 316.647.82:37.016:811.111] 811.111'42

DOI https://doi.org/10.24919/2308-4863/42-1-37

Olena HALAI,

orcid.org/0000-0001-6139-4726

Senior Lecturer at the Department of the English Language and Methods of Teaching

Pavlo Tychyna Uman State Pedagogical University

(Uman, Cherkasy region, Ukraine) o.halai@udpu.edu.ua

\title{
INVESTIGATING THE THEME OF DISCRIMINATION THROUGH AUTHENTIC TEXTS AT ENGLISH LESSONS
}

The article deals with the social issue of discrimination in general and in the context of the education sector. Discrimination is considered as a phenomenon whose negative impact extends to all spheres of public life. The fight against discrimination is complicated by the fact that it depends on perceptions or subjective opinions and biases about people's abilities and attitudes. Discrimination is common in the field of education, which has a detrimental effect on school students, especially those who are somewhat different from others.

To ensure that the needs of all students are met equally, schools need to give priority to language and cultural competencies, diversity in history and gender equality. In this way, students can acquire the skills of democratic culture to realize their potential both in school and in society.

Discrimination can occur in almost any aspect of school life, from the attitudes and expectations of teachers to school rules and codes of conduct, selection and grouping practices, curricula, teaching methods and materials, changing facilities, career guidance, canteen food and the physical school environment.

Whatever form it takes - whether it's parallel school systems for different ethnic groups, the concentration of minority or disadvantaged children in the same school, or differentiated access to education - this means a lower quality of education for students who are discriminated against.

Ensuring that all students of all ages are provided with equal, high-quality educational opportunities requires a school-wide approach. The starting point should be to assess the current situation, identify the strengths that exist in the school, as well as the needs and priorities of students.

The central place in this process takes the fight against negative stereotypes, both in the classroom and during extracurricular activities. Thus, foreign language lessons can become one of the tools in overcoming stereotypical thinking and, as a result, discrimination among educational applicants. In particular, working with authentic text, in which you can distinguish stereotypical images and roles, is an effective method. The article describes the proposed methods and techniques that can be used in the English lesson.

Key words: discrimination, prejudice, stereotype, literary characters, methods.

Олена ГАЛАЙ, orcid.org/0000-0001-6139-4726

старший викладач кафедри англійської мови та методики ї̈ навчання Уманського держсавного педагогічного університету імені Павла Тичини (Умань, Черкаська область, Україна) о.halai@udpu.edu.иа

\section{ДОСЛІДЖЕННЯ ТЕМИ ДИСКРИМННАЦІЇ НА УРОКАХ АНГЛІЙСЬКОЇ МОВИ НА ОСНОВІ АВТЕНТИЧНИХ ТЕКСТІВ}

У статті розглядається сочіальне питання дискримінаџії загалом та в розрізі сфери освіти. Дискримінація розглядається як явище, негативний вплив якого поширюється на всі сфери суспільного життя. Боротьба з дискримінацією ускладнюється тим, щңо вона залежить від сприйняття чи суб'єктивної думки й упередження про здібності і настанови людей. Прояви дискримінації наявні у сфері освіти, щчо має шкідливий вплив на учнів шкіл, особливо на тих, хто якось вирізняється серед інших.

Щоб забезпечити рівне задоволення потреб усіх учнів, школам необхідно приділяти пріоритетну увагу мовним і культурним компетенціям, багатоплановості в історії та тендерній рівності. Так учні можуть набути навичок демократичної культури, щьоб реалізувати свій потенціал як у школі, так $і$ в суспільстві.

Дискримінація може проявлятися в будь-якому аспекті шкільного життя, від ставлення й очікувань учителів до шкільних правил $і$ кодексів поведінки, практики відбору і групування, навчальних програм, методів $i$ матеріалів навчання, змінних приміщень, професійної орієнтації, харчування в їдальні і фізичного шкільного середовища.

Якої б форми иче не набувало - будь то паралельні шкільні системи для різних етнічних груп, концентрація дітей із числа меншин або дітей, щзо перебувають у несприятливому становищі, в тій самій школі або диференційований доступ до освіти, це означає більш низьку якість освіти для учнів, які піддаються дискримінації. 
Забезпечення того, щзоб усім учням будь-якого віку надавалися рівноцінні високоякісні освітні можливості, вимагає загальношкільного підходу. Точкою відліку має стати оцінка поточної ситуачії, визначення сильних сторін, наявних у школі, а також потреб і пріоритетів учнів.

Центральне місие в цььому процесі належить боротьбі з негативними стереотипами як на уроках, так $і$ під час позаурочної діяльності. Так, уроки іноземних мов можуть стати одним з інструментів у подоланні стереотипного мислення та, як наслідок, проявів дискриміначії серед здобувачів освіти. Зокрема, робота з автентичним текстом, у якому можна виділити стереотипні образи, ролі, є дієвим методом. У статті описані пропоновані методи та прийоми, які можуть бути використані на уроці англійської мови.

Ключові слова: дискримінація, упереджене ставлення, стереотип, літературні образи, методи.

Problem statement. The word "discrimination" means separation, division, distinction. In the legal encyclopedia, it is understood as deliberate restriction or deprivation of the rights of individuals and legal entities (Shemshuchenko, 1998: 165) It is a phenomenon that has a negative impact on all spheres of life. Discrimination can have a damaging effect on learners as well, especially those who are targeted.

To ensure that all students' needs are met equally, schools need to prioritise language and cultural competences, multiperspectivity in history and gender equality. In this way, students can acquire competences for democratic culture, to fulfil their potential in school as well as in society.

Research analysis. The works of both domestic and foreign scientists, such as O. R. Dashkovska (Dashkovska, 2008), O. M. Korshunova (Korshunova, 1973), I. O. Kresina (Kresina, 2015), I. A. Kretova-Alioshina (Kretova-Alioshina, 2012), V. I. Kruss (Kruss, 2005), O. Z. Pankevch (Pankevch, 2014), S. P. Pogrebniak (Pogrebniak, 2007), S. P. Rabinovich (Rabinovich, 2014), O. M. Rudneva (Rudneva, 2010) and others, are devoted to the problems of discrimination.

Discrimination can occur in almost any aspect of school life, from the attitudes and expectations of teachers to school rules and codes of conduct, selection and grouping practices, curricula, teaching methods and materials, changing facilities, career guidance, canteen food and the physical school environment.

Whatever form it takes - whether it be parallel school systems for different ethnic groups, concentrations of minority or disadvantaged children in the same school, or differential access to educational provision, it means a lower quality of educational experience for the students being discriminated against.

Children and young people who are treated unfairly or discriminated against are more likely to have:

- negative attitudes to school;

- lower levels of motivation and academic achievement;

- a higher risk of dropping out of formal education;
- experience of bullying;

- mental health problems.

Ensuring all learners of any age are provided with meaningful, high-quality educational opportunities alongside their peers requires a wholeschool approach. A good place to start is with an assessment of the current situation, identifying the strengths that exist in the school, but also needs and priorities.

Schools can then turn to the longer-term aspiration of creating a culture of non-discrimination. Central to this process is the challenging of negative stereotyping, both in classrooms and around the school. This can be done in a variety of ways, including:

- challenging stereotypes when they are heard;

- discussing stereotypes with students;

- identifying stereotypes in the curriculum;

- highlighting stereotypical images and roles in textbooks.

Purpose of the article. To outline the suggested activities which can be possibly used at English lessons to challenge discrimination.

Presentation of the basic material. For this purpose we have chosen extracts from an essay by Bruno Bettelheim and from the novel Ragtime by E. I. Doctorow. These passages deal with the experiences of Bruno Bettelheim, a Jewish psychologist interned in a Nazi labor camp and Coalhouse walker, African-American protagonist, a successful musician in New York City. Both of them present students with the central characters' experiences of prejudice and portray their reactions to the treatment they receive at the hands of their oppressors.

Phase One: Leading Students into the Text

All the activities in this section focus on personal experience, a powerful means of focusing student attention/ Each activity asks the students to reflect on incidents of prejudice in their own lives, or on their thoughts and feelings about situations involving discrimination they have observed. All are designed to "build bridges" to the passages they will read/ Through recalling their own feelings, students are encouraged to identify with the experiences of the characters in the literary pieces and central themes their authors are presenting. 


\section{Clustering Activity - "Discrimination" Word Wheel}

This is a potent method for examining many dimensions of a subject. It involves the whole class and gives the individual students material to help recall incidents from personal experience. For this blackboard clustering activity, the word discrimination is written in capital letters in the center of the blackboard, it is circled, and the lines are drawn emanating out of the circle. The students are asked to write the ideas as for the kinds of things that people discriminate against.

On completing the wheel students are asked to brainstorm incidents of discrimination they have observed or experienced.

\section{Visualization - Being Imprisoned}

Guided visualization stirs the imagination and is a very powerful tool for recreating experience. Students may need to be taught the techniques of visualization. Closing the eyes to see pictures may not come easily to some students, and they may need practice to be comfortable. A teacher may read the visualization exercise aloud to students, writing the words elicited from students on the blackboard and clustering like lexical sets together. Follow-up discussion should ensue.

\section{Journal Prompt - Experience with Prejudice}

Even more than the clustering activity, this enables students to reflect on personal experience or observations that relate to the themes they are about to encounter in the literary works. It also gives them a chance to use their personal voice to articulate these thoughts on paper. As a prompt students can make use of the following questions: Have you ever experienced prejudice? What do you think the cause of this prejudice was? Students can write about an event they witnessed or one where they personally were the victim of prejudice.

\section{Anticipation/Reaction Guide}

Examining attitudes before reading and contrasting them with attitudes after reading make students aware of the power of text. Seeing with different eyes, one often modifies opinions and gains insight. Changing and broadening attitudes are among the major purposes of this activity. The anticipation / reaction guide below is used as a pre- and postreading exercise. Prior to reading the Bettelheim and Walker selections, students are asked individually to check off left-hand column of the worksheet with their personal reactions. Then, following the reading of the passage, they are asked to check the right-hand column. Students discuss any changes of opinion.

Phase Two: Assisting Students through the Text

These "through" activities focus on the texts themselves and lead students to close reading. The emphasis shifts to the authors - what they have to say, what their purposes are. The student is involved in unlocking meaning as the graphic organizers make abstract ideas visual and concrete and thus more easily understood.

Strip Story / Sentence Strip Activity

By reconstructing a key paragraph from the text in proper sentence order, the student experiences exactly the ways in which the author creates meaning. This heightens anticipation of the story, which students have not yet read in its entirety, and sharpens reading skills.

Each sentence of the key paragraph is typed on a strip of paper. Each group of students is given the background to the story and the sentence strips (in jumbled order); groups are then asked to rearrange these sentences in proper narrative order. This adaptation of the activity may be more appropriate for students whose listening skills are weak, or for classes where teachers wish to focus on coherence in written discourse.

\section{Jigsaw Reading}

Each member of the group becomes a "teacher" in this activity. It is an effective teaching tool in several ways: Students have the support of a peer group, called their "expert" group, as they locate the main ideas in their assigned paragraphs, and they also have teaching responsibility to deliver the central meaning of one paragraph to the home group in which they begin and end the activity. This exercise guarantees participation of each member of the group.

\section{Paraphrase Activity}

Presenting students with paraphrases of passages they have already read helps them to gain an appreciation for the richness of the English language and to grasp more concretely the meaning of the original passages. Presenting students with paraphrases in this fashion is a necessary precedent to asking them to write their own paraphrases - a skill that requires much practice on their part. The following five sentences represent central ideas from the Coalhouse Walker and Bruno Bettelheim readings. However, these sentences do not use the original words of the authors; instead, they are paraphrases of the original passage.

Vocabulary Building - Personal Characteristics

This exercise provides students with a set of vocabulary items useful for comparing the characteristics of the protagonists in the two pieces. Understanding the personalities of the characters is central to unlocking meaning in these pieces. Students are provided with the vocabulary necessary to make comparisons between the central characters. They are also given a graphic organizer that helps them to com- 


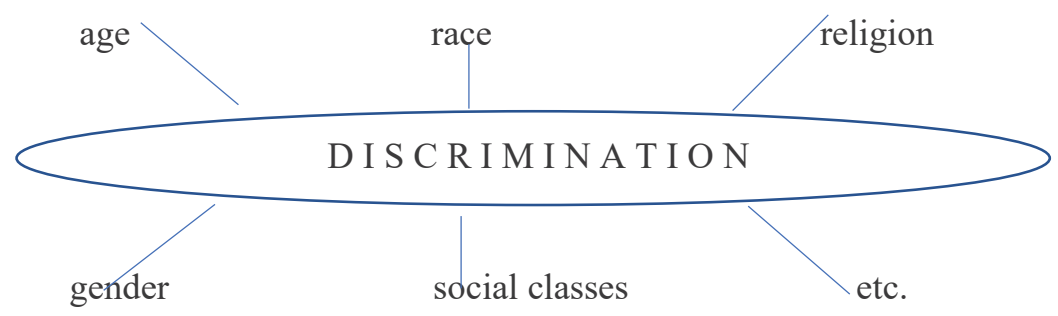

Table 2

\begin{tabular}{|l|l|l|l|l|}
\hline Agree & Disagree & & Agree & Disagree \\
\hline & & 1. People who suffer often deserve the treatment they get. & & \\
\hline & 2. You can always get help from a policeman. & & \\
\hline & 3. Manipulation is better than resistance. & & \\
\hline & $\begin{array}{l}\text { 4. There is often good reason to mistrust people of different } \\
\text { races or ethnicities. }\end{array}$ & & \\
\hline & 5. Everuone responds to human suffering by offering help. & & \\
\hline & $\begin{array}{l}\text { 6. People who have more than other people are more able to } \\
\text { take care of themselves. }\end{array}$ & & \\
\hline & 7. Justice comes when a case is argued clearly. & \\
\hline & 8. Certain ethnic groups have too much power and influence. & & \\
\hline & $\begin{array}{l}\text { 9. Minority group members should be kept in their place in } \\
\text { society and should not overstep their bounds. }\end{array}$ & $\begin{array}{l}\text { 10. Through history, we have learned from the mistakes of the } \\
\text { past. }\end{array}$ & \\
\hline
\end{tabular}

Table 3

1. Paraphrase: If one of the captives begged for mercy, the officer became angry and cruel.

Original Text:

2. Paraphrase: They don't intend to cause any damage. In all likelihood, they have lost interest and aren't amused any more.

Original Text:

3. Paraphrase: Throughout the past, he had dealt with these sentiments.

Original Text:

4. Paraphrase: Once we had entered, he glared at me and shoved me into the examining room.

Original Text:

5. Paraphrase: $\underline{\text { Set in the rear seat of the car was a pile of human waste. }}$

Original Text:

pare Bettelheim and Walker visually. Students are to decide whether the two characters have a high or a low amount of the qualities named at the left using $X$ for Bettelheim and $O$ for Walker.

Illustrating Quotations

This activity allows students to select their own key quotations from the materials they have read to illustrate these quotations. Thus, students are encouraged to exercise their own judgements of significance, an important step toward awakening in them critical awareness. If students can make an idea visual, they usually have grasped it thoroughly and will remember it.

A Venn diagram provides a useful tool for students to compare the two characters and graphically map out their similarities and differences. Building on the information students have gathered in the other comparison-contrast exercises, it makes a good culminating activity for this stage of the students' literary journey.

Phase Three: Leading Students beyond the Text

The purpose of the "beyond" activities is synthesis. Once the students have unlocked meaning in the pieces and have seen relationships between the experiences of these characters and their own experience, they are ready to synthesize these ideas and use them to create their own pieces of analytical writing. These activities use the reding as a foundation and ask the student to become a writer. 


\begin{tabular}{|lc|}
\hline deference LOW & HIGH \\
sensitivity LOW & HIGH \\
anxiety LOW & HIGH \\
independence LOW & HIGH \\
arrogance LOW & HIGH \\
openness LOW & HIGH \\
intelligence LOW & HIGH \\
\hline
\end{tabular}

Table 5

\begin{tabular}{|l|l|l|}
\hline \multicolumn{1}{|c|}{ Coalhouse Walker } & \multicolumn{1}{c|}{ Both } & \multicolumn{1}{c|}{ Bruno Bettelheim } \\
\hline Black-race & brave & Jew-religion \\
\hline Impulsive & gusty & restrained \\
\hline confrontive & discriminated against & matter-of-fact \\
\hline determined & show power & calm \\
\hline arrogant & negative+ positive & smart \\
\hline powerless & & powerful \\
\hline does not "hear" enemy & & "hears" the enemy \\
\hline
\end{tabular}

\section{Writing a Letter Home}

This activity requires the student to delve into the personality of the literary figure and to become that person. This personalized writing allows students to examine - from within - the motivations and conflicts. In this writing task, students assume the role of either Bruno Bettelheim or Coalhouse Walker writing a letter to his wife, who cannot visit him because he is imprisoned. The student is to decide whether the chosen character will be truthful about the conditions he is experiencing, or he will protect his wife from this information. Students are free either to show their anger and frustration or hide it and pretend that all is well.

\section{Dramatization}

This activity of "being" the character forces students to take on the thoughts and feelings of the per- son they are portraying. "Becoming" the character takes students one step beyond discussion questions, and forces them to search for an inner rationale for their characters' thoughts and actions.

Conclusion. Thus, the simple presentation of a text does not guarantee understanding and enjoyment for language students. With their developing linguistic abilities and differing cultural frames of reference, the students can be intimidated initially by the many lexical, cultural and stylistic hurdles in a text. But through carefully selected activities, students can recognize bits and pieces of themselves and their life experiences or knowledge bases in the ideas they encounter in a given reading passage. With guidance they recognize these parallels, and through close reading they find the evidence they need to reason effectively and to support their arguments.

\section{BIBLIOGRAPHY}

1. Дашковська О. Р. Правове становище жінки в аспекті гендерної рівності : загальнотеоретичний аналіз : дис. ... докт. юрид. наук. Харків, 2008. 392 с.

2. Коршунова Е. Н. Дискриминация граждан в капиталистических странах. Москва : Юрид. лит., 1973. 215 с.

3. Запобігання дискримінації в Україні в контексті європейської інтеграції : монографія / І. О. Кресіна та ін. Київ : Інститут держави і права ім. В. М. Корецького НАН України, 2015. 384 с.

4. Кретова-Алешина И. А. Конституционный принцип недискриминации в Российской Федерации : дис. ... канд. юрид. наук : 12.00.02. Саратов, 2012. 166 с.

5. Крусс В. И. Дискриминация и дифференцированный подход к обладателям конституционных прав и свобод. Государство и право. 2005. № 12. С. 30-42.

6. Погребняк С. П. Роль принципу недискримінації в загальній концепції рівності. Вісник Академії правових наук України. 2007. Вип. 3 (50). С. 23-34.

7. Рабінович С. П., Панкевич О. 3. Принципи рівності й недискримінації в конституційному правосудді України. Право і громадянське суспільство. 2014. № 2 (7). С. 147-170.

8. Руднєва О. М. Поняття й сутність принципу недискримінації. Проблеми законності : збірник наукових праць. 2010. Вип. 110. С. 9-16.

9. Шемшученко Ю. С. Юридична енциклопедія : у 6-и т. Київ : Укр. енцикл., 1998. Т. 2 : Д - Й. 744 с. 


\section{REFERENCES}

1. Dashkovska O. R. Pravove stanovushche zhinky v aspecti hendernoi rivnosti : zahalno-teoretychnyi analiz [Legal status of women in the aspect of gender equality: general theoretical analysis] : dys. ... d-ra yuryd. nauk. Kharkiv, 2008,392 p. [in Ukrainian].

2. Korshunova E. N. Discriminatsia grazhdan v kapitalisticheskih stranah [Discrimination of citizens in capitalist countries]. Moscva : Yurid. lit., 1973. 215 p. [in Russian].

3. Zapobihannia dyscryminatsii v Ukraiini v konteksti yevropeiskoii intehratsii [Prevention of discrimination in Ukraine in the context of European integration] : monohraphiia / I. A. Kresina, K. M. Witman, V. P. Horbatenko ta in. Kyiv : Instytut derzhavy i prava im. V. M. Koretskoho NAN Ukraiiny, 2015. 384 p. [in Ukrainian].

4. Kretova-Alioshyna I. A. Konstitutsyonnyi printsyp nedescriminatsyi v Rossiiskoi Federatsyi [The constitutional principle of non-discrimination in the Russian Federation] : dis. ... cand. yurid. nauk: 12.00.02 / Saratovskii gosudarsvennyi universitet imeni N. G. Chernyshevskogo. Saratov, 2012. 166 p. [in Russian].

5. Kruss V. I. Discriminatsyya i diferentsyrovanyi podhod k obladatielyam konstitutsyonnyh prav i svobod [Discrimination and a differentiated approach to the holders of constitutional rights and freedoms]. Gosudarstvo i pravo. 2005 . № 12. P. 30-42 [in Russian].

6. Pohrebniak S. P. Rol pryntsypu nedescryminatsii v zahalnii kontseptsii rivnosti [The role of the principle of nondiscrimination in the general concept of equality]. Visnyk akademii pravovyh nauk Ukraiiny. 2007. Issue 3 (50). P. 23-34 [in Ukrainian].

7. Rabinovych S. P., Pankevych O. Z. Pryntsypy rivnosti j nedyscryminatsii v konstytutsiinomy pravosuddi Ukrainy [Principles of equality and non-discrimination in constitutional justice of Ukraine]. Pravo I hromadianske suspilstvo. 2014. № 2 (7). P. 147-170 [in Ukrainian].

8. Rudnieva O. M. Poniattia $\mathrm{j}$ sutnist pryntsypu nedescryminatsii [The concept and essence of the principle of nondiscrimination]. Problemy zakonnosti : zb. nauk. prats. 2010. Issue 110. P. 9-16 [in Ukrainian].

9. Shemshuchenko Yu. S. Yurydychna entsyklopediia [Juridical Encyclopedia] : v 6 t. Kyiv : Ukr. entsykl., 1998. Vol. 2 : D - J. 744 p. [in Ukrainian]. 